УДК 621.575.932:621.565.92

А. С. Титлов, Ю. А. Очеретяный, А. О. Холодков, А. В. Остапенко

Одесская национальная академия пищевых технологий, Канатная, 112, Одесса, 65039, Украина

\title{
РАЗРАБОТКА И ИССЛЕДОВАНИЕ ГЕНЕРАТОРОВ ТРАНСПОРТНЫХ АБСОРБЦИОННЫХ ХОЛОДИЛЬНЫХ ПРИБОРОВ
}

Представлены результаты экспериментальных исследований абсорбционного транспортного холодильника «Киев» АЛ-35 с горелочными устройствами, которые показали его работоспособность при использовании различных доступных органических теплоносителей (этиловый спирт, керосин, сжиженный пропан) в транспортных условиях, в частности, на малой морской яхте. Разработано оригинальное горелочное устройство с применением каталитического источника горения, которое может решать задачи обеспечения требуемых режимов охлаждения при минимальных расходах пропана в качестве теплоносителя.

Ключевые слова: Абсорбиионный холодильник; Горелочное устройство; Интенсификаторы горения.

О. С. Тітлов, Ю. О. Очеретяний, А. О. Холодков, О. В. Остапенко

Одеська національна академія харчових технологій, Канатна, 112, Одеса, 65039, Україна

\section{РОЗРОБКА І ДОСЛІДЖЕННЯ ГЕНЕРАТОРІВ ТРАНСПОРТНИХ АБСОРБЦІЙНИХ ХОЛОДИЛЬНИХ ПРИЛАДІВ}

Представлені результати експериментальних досліджень абсорбиійного транспортного холодильника «Київ» АЛ-35 з пальниковими пристроями, які показали його працездатність при використанні різних доступних органічних теплоносіїв (етиловий спирт, гас, зріджений пропан) в транспортних умовах, зокрема, на малій морської яхті. Розроблено оригінальний пальниковий пристрій із застосуванням каталітичного джерела горіння, щзо дозволить вирішувати завдання забезпечення необхідних режимів охолодження при мінімальних витратах пропану в якості теплоносія.

Ключові слова: Абсорбиійний холодильник; Пальниковий пристрій; Інтенсифікатори горіння.

This work is licensed under the Creative Commons Attribution International License (CC BY). http://creativecommons.org/licenses/by/4.0/

\section{I. ВВЕДЕНИЕ}

На маломасштабных транспортных объектах (авто и железнодорожном, морском и авиатранспорте) особый интерес вызывает использование абсорбционных холодильных приборов (АХП), в состав которых входят безнасосные абсорбционные холодильные агрегаты (АХА). Такой интерес связан, в первую очередь, с возможностью работы АХА с неэлектрическими источниками тепловой энергии, в том числе и бросовой, например, с использованием теплоты выхлопных газов двигателей внутреннего сгорания. Работа же компрессионных и термоэлектрических моделей холодильников предполагает наличие либо аккумуляторных батарей, либо дополнительного топлива для дизель-генератора, что увеличивает вес транспортного средства и затраты энергоносителей.

Кроме этого к традиционным преимуществам AХА относят экологическую безопасность рабочего тела, бесшумность в работе, высокую надежность и длительный ресурс.
Наибольшее удельный вес в ассортименте АХП транспортного типа имеют минимодели с объемом холодильной камеры от 35 до 40 дм $^{3}$ и с комбинированными источниками энергии (два электрических нагревателя на переменном и постоянном токе плюс горелочное устройство). Для повышения надежности в условиях внешних динамических нагрузок АХА в составе минимоделей имеют упрощенную конструкцию элементов и узлов $[1,2]$. Существенным недостатком таких АХА является минимум энергосберегающих технических решений и, соответственно, повышенное удельное энергопотребление по сравнению с моделями АХА в составе холодильников среднего (от 100 до 170 дм $^{3}$ ) и высокого объема (от 220 до 400 дм $^{3}$ ) [3]. К тому же в настоящее время имеется только фрагментарная информация по режимам работы минимоделей АХП, а это не позволяет в полной мере провести энергосберегающие мероприятия. Такое положение сдерживает дальнейшее развитие минимоделей АХП и снижает привлекательность на рынке транспортной холодильной техники. 
Таким образом, исследования, касающиеся повышения энергетической эффективности в транспортных условиях, являются актуальными.

\section{II. АНАЛИЗ КОНСТРУКЦИЙ СОВРЕМЕННЫХ ГОРЕЛОЧНЫХ УСТРОЙСТВ}

Источником тепловой энергии типичного горелочного устройства является теплота сгорания ископаемых видов углеводородного топлива: нефти с ее производными и природного газа. Высвобождение теплоты сгорания топлива осуществляется в процессе сжигания его в смеси с окислителем, в большинстве случаев - с кислородом воздуха.

Для эффективного сжигания топлива горелочное устройство выполняет следующие функции:

a) подготавливает топливо и воздух для горения, придавая им требуемые направления и скорости движения (в некоторых случаях в горелке происходит предварительный подогрев газа или воздуха);

б) подготавливает горючую смесь (смешивает газообразное топливо и воздух или распыляет жидкое топливо и смешивает его с воздухом);

в) осуществляет подачу подготовленной горючей смеси в рабочее пространство или топку;

г) стабилизирует воспламенение.

В зависимости от типа горелочное устройство может предназначаться для выполнения только части перечисленных функций.

Процесс сжигания газообразного топлива можно условно разделить на три стадии:

a) смешение топлива с воздухом для горения;

б) подогрев топливовоздушной смеси до температуры воспламенения;

в) собственно процесс горения, т.е. реакция окисления горючих компонентов топлива кислородом воздуха, которая протекает практически мгновенно.

Первые две стадии требуют гораздо больше времени, и по этой причине организация смешения в значительной степени определяет весь процесс сжигания, характеристики факела и, следовательно, распределение температур в рабочем пространстве топочной камеры.

Газовые горелки - относительно новый класс газового оборудования, особенно для Украины. В широкой продаже газовые горелки стали появляться в 90-х годах XX века, а до этого их нишу прочно занимали различные виды примусов, работающих на бензине и керосине. В наше время газовые горелки все шире распространяются в мире туризма, ввиду наличия у них ряда важных достоинств, существенно помогающих туристу в походе. Всего существуют три основных вида горелок: газовые, жидкотопливные, (бензин, керосин и некоторые другие), и мультитопливные. Термин “мультитопливные" применяется к двум видам горелок: тем, которые могут работать на нескольких видах жидкого топлива, и тем, которые могут работать как на бензине, так и на газе. Есть еще и другие классы горелок, например, спир- товые, но большого распространения в туризме они не получили.

Газовые горелки обладают целым спектром разнообразных достоинств.

Во-первых, процедура запуска горелки занимает даже не минуты, а секунды. Во-вторых, работают они практически безотказно, ибо отличаются простотой конструкции. В-третьих, такие горелки не склонны ко взрывам и выбросам языков пламени, в отличии от их бензиновых аналогов. Благодаря этому, газовую горелку можно эксплуатировать в закрытых помещениях, в том числе гостиницах, кемпингах и даже палатках.

Газовая горелка работает более тихо, чем бензиновая. Наконец, газовая горелка в разобранном виде занимает мало места, и стоит дешево. Принципиальными для выбора горелок являются два параметра: тепловая мощность и конструктивные особенности горелки.

Сравнительный анализ газовой и жидкотопливной горелки приведен в таблице 1.

Основными мероприятиями по экономии энергоресурсов и повышению эффективности использования горелочных устройств в АХП могут быть: a) определение нагрузки и качества сжигания топлива, проведение соответствующих регулировок режимов работы горелок; б) уменьшение температуры отходящих газов путем предварительного нагрева нагнетаемого воздуха с помощью рекуперативных горелок, рекуператоров или регенераторов; в) обеспечение необходимого аэродинамического режима работы горелочного устройства; г) оптимизация процесса теплообмена, а также оптимальное размещение горелочного устройства; д) сведение к минимуму потерь тепла путем установки оборудования для автоматической регулировки температуры, времени работы и других рабочих параметров.

Значительные потери тепловой энергии происходят при работе с открытым вытяжным каналом для уходящих газов. Характерной особенностью этого является наличие высоких температур дымовых газов, уходящих в атмосферу.

В качестве основных мероприятий по экономии тепловой энергии и повышению эффективности использования горелочных устройств в составе АХП могут быть рекомендованы: а) минимизация тепловых потерь через технологические проемы; б) согласование процессов в цикле АХА с процессами горения с точки зрения потребления энергии; в) сведение к минимуму уровня тепловых потерь разогретых поверхностей путем их изолирования в максимальной степени; г) применение современных концепций управления работой оборудования, в частности, методов пропорционального управления, микрокомпьютеров и вычислительных устройств; д) устройства постоянного контроля, как температуры отходящих газов, так и содержания в них $\mathrm{NO}_{2}$, $\mathrm{CO}_{2}, \mathrm{CO}$ для обеспечения максимальной эффективности и качества сгорания топлива при любой тепловой нагрузке. 
Tаблица 1 - Сравнительный анализ достоинств и недостатков горелок

\begin{tabular}{|c|c|c|c|}
\hline $\begin{array}{l}\text { № } \\
\text { II/II }\end{array}$ & $\begin{array}{c}\text { Описание достоинства / } \\
\text { недостатка }\end{array}$ & Газовая горелка & Жидкотопливная \\
\hline 1 & $\begin{array}{l}\text { Скорость разведения горелки, } \\
\text { включая её сборку (подсоеди- } \\
\text { нение баллонов, разогрев, } \\
\text { нагнетание давления и т.п.) }\end{array}$ & Менее 1 минуты & 3-7 минут \\
\hline 2 & $\begin{array}{l}\text { Наличие копоти при эксплуата- } \\
\text { ции }\end{array}$ & Нет & Есть \\
\hline 3 & $\begin{array}{l}\text { Взрыво- и } \\
\text { пожаробезопасность }\end{array}$ & $\begin{array}{l}\text { Практически } \\
\text { взрывопожаробезопасна }\end{array}$ & $\begin{array}{l}\text { Горелки представляют опреде- } \\
\text { ленную опасность, обращение с } \\
\text { ними требует навыка }\end{array}$ \\
\hline 4 & Удобство перевозки & $\begin{array}{l}\text { Большинство горелок легко } \\
\text { отсоединяются от баллона и } \\
\text { легко перевозятся. Газовые бал- } \\
\text { лоны нельзя перевозить в само- } \\
\text { летах }\end{array}$ & $\begin{array}{l}\text { Пустые горелки могут легко } \\
\text { перевозиться. Горелки с заправ- } \\
\text { ленным топливом могут причи- } \\
\text { нять беспокойство (возможно } \\
\text { появление запаха). Горелки с } \\
\text { бензином в баке нельзя перево- } \\
\text { зить в самолетах }\end{array}$ \\
\hline 5 & $\begin{array}{l}\text { Возможность эксплуатации в } \\
\text { закрытых помещениях }\end{array}$ & $\begin{array}{l}\text { За исключением помещений, } \\
\text { где запрещен открытый огонь в } \\
\text { любых видах }\end{array}$ & $\begin{array}{l}\text { Крайне не рекомендуется из-за } \\
\text { образования копоти и вероятно- } \\
\text { сти возгорания. }\end{array}$ \\
\hline 6 & Удобство пользования & $\begin{array}{l}\text { Не требует специальных навы- } \\
\text { ков }\end{array}$ & $\begin{array}{l}\text { Требует определенных знаний и } \\
\text { навыков }\end{array}$ \\
\hline 7 & Топливо и его доступность & $\begin{array}{l}\text { Газовые баллоны существенно } \\
\text { уступают по распространенно- } \\
\text { сти бензину, зато купленный } \\
\text { баллон является гарантией ка- } \\
\text { чества топлива }\end{array}$ & $\begin{array}{l}\text { Топливо распространено по- } \\
\text { всеместно в любой точке мира, } \\
\text { однако, его качество может } \\
\text { явиться существенной пробле- } \\
\text { мой. Плохое топливо приводит } \\
\text { к неустойчивой работе горелок, } \\
\text { их засорению и необходимости } \\
\text { в ремонте. }\end{array}$ \\
\hline 8 & $\begin{array}{l}\text { Наличие побочных проблем с } \\
\text { топливом }\end{array}$ & Нет & $\begin{array}{l}\text { Обладает неприятным запахом, } \\
\text { требует определенного внима- } \\
\text { ния при перевозке, хорошей } \\
\text { тары. }\end{array}$ \\
\hline 9 & $\begin{array}{l}\text { Другие эксплуатационные про- } \\
\text { блемы }\end{array}$ & $\begin{array}{l}\text { Чувствительность к работе при } \\
\text { низких температурах (ниже } \\
\left.10^{\circ} \mathrm{C}\right) . \text { Наблюдается снижение } \\
\text { мощности из-за падения давле- } \\
\text { ния газа внутри баллона, по } \\
\text { мере его эксплуатации }\end{array}$ & $\begin{array}{l}\text { Часто ломается. Конструкция } \\
\text { горелки более сложная, чув- } \\
\text { ствительная к чистоте топлива, } \\
\text { требует чистки. Более шумно } \\
\text { работает }\end{array}$ \\
\hline 10 & Стоимость & $\begin{array}{l}\text { Стоят относительно дешево, а } \\
\text { топливо к ним относительно } \\
\text { дорого }\end{array}$ & $\begin{array}{l}\text { Стоят довольно дорого, а топ- } \\
\text { ливо к ним довольно дешево }\end{array}$ \\
\hline 11 & Надежность работы & Практически безотказна & Относительно низкая \\
\hline
\end{tabular}

\section{III. РЕЗУЛЬТАТЫ ЭКСПЕРИМЕНТАЛЬНЫХ ИССЛЕДОВАНИЙ}

Эффективное решение задачи модернизации существующих горелочных устройств для их экономной и безопасной эксплуатации АХП, работающих в стационарных и транспортных условиях возможно, прежде всего, за счет применения современного высокоэффективного отечественного и зарубежного газового оборудования с КПД до 95\% и практически полным сгоранием органического топлива.

С учетом приведенных выше соображений по методам повышения энергетической эффективности горелочных устройств была предложена конструкция генераторного узла с турбулизатором потока продуктов сгорания (рис. 1) [4]. Турбулизатор устанавливали в гильзе электронагревателя. Длина турбулизатора во всех случаях составляла $0,1 \mathrm{M}$. 


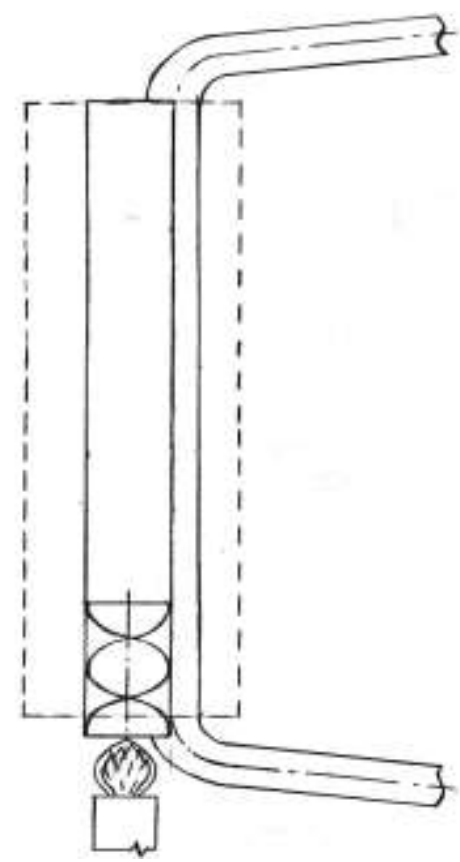

Рисунок 1 - Схема генераторного узла с дымовой трубой и турбулизатором потока продуктов сгорания.

На рисунке 2 представлен эскиз оригинального инфракрасного горелочного устройства с каталити- ческим процессом горения.

В горелочном устройстве за счет установки специального керамического элемента-катализатора осуществляется окисление газа кислородом воздуха на поверхности катализатора. Конструкция горелки позволяет создать качественную воздушно-газовую смесь и равномерно распределить пламя по всей поверхности катализатора. Это достигается за счет того, что смесительная камера 6 выполнена в виде трех расположенных равномерно по окружности корпуса отверстий, через которые осуществляется эжектирующий подсос наружного воздуха для равномерного смешивания с минимальной струей газа, выходящего из форсунки 2. Далее газовоздушная смесь равномерно с номинальной скоростью поступает в нижнюю часть катализатора 9, функцию которого выполняет керамический элемент.

Изучались два способа подвода тепла к генераторному узлу - через серийную гильзу с открытым вытяжным каналом для уходящих газов и с турбулизатором потока (медным и жестяным), вставленным в штатную гильзу генераторного узла.

В основе методики лежат требования нормативных документов [5, 6] относительно испытаний бытовых холодильных приборов с измерением температур в характерных точках полезного объема холодильной камеры и окружающей среды.

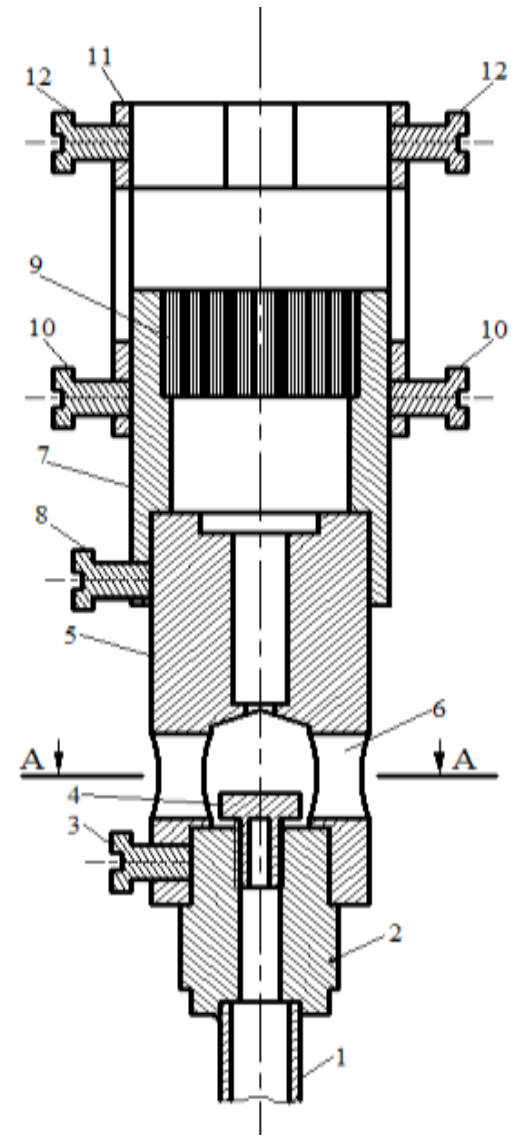

a)

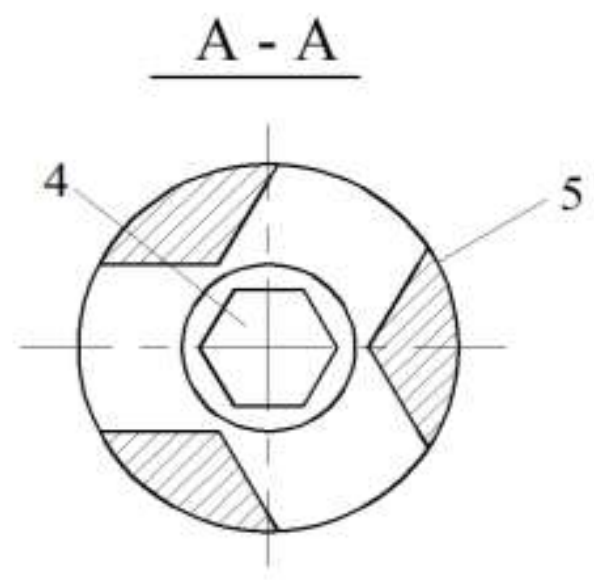

Рисунок 2 - Эскиз инфракрасного горелочного устройства с каталитическим процессом горения: а) общий вид (разрез); б) сечение А-А. 
Обозначения к рисунку 2: 1 - каналы для входа газа; 2 - форсунка; 3, 8, 10, 12 - болты крепления элементов горелки; 4 - регулятор расхода газа; 5 камера смешения; 6 - отверстия для подсоса (эжекции) наружного воздуха; 7 - камера сгорания; 9 керамический катализатор; 11 - цилиндр крепления горелки к гильзе генераторного узла АХА; 12 - бол- ты крепления горелки к нижней части гильзы генераторного узла АХA.

Дополнительно в исследуемых объектах регистрировалась температура в характерных точках AXA (рисунок 3): а) нижняя часть змеевикового абсорбера - 5; б) выход испарителя - 4; в) конденсатор - 3 ; г) генератор - 1; д) дефлегматор - 2; е) центр ЖТО - $6[93,94]$.

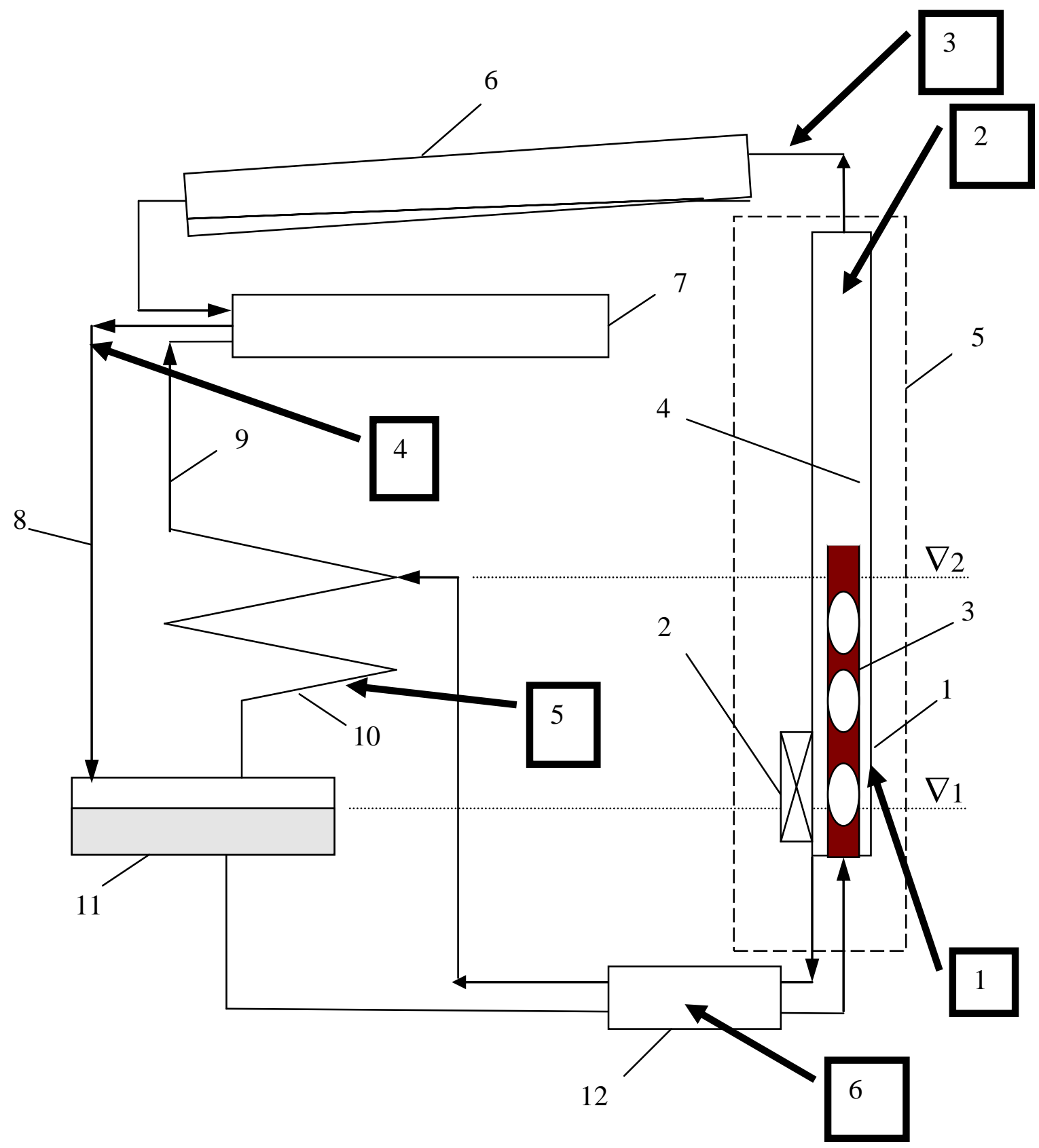

Рисунок 3 - Схема установки термопар в характерных точках AXА.

Обозначения к рисунку 3: 1 - генератор; 2 электронагреватель; 3 - термосифон; 4 - дефлегматор; 5 - теплоизоляционный кожух; 6 - конденсатор; 7 - испаритель; 8 (9) - опускная (подъемная) магистраль парогазового контура; 10 - абсорбер; 11 - ресивер жидкого раствора; 12 - ЖТО; $\nabla 1$ и $\nabla 2$ - уровень крепкого и слабого ВАР, соответственно; $1 \ldots 6-$ места установки термопар
На первом этапе исследований проводилось изучение места положения горелки относительно жарового стакана генератора. По результатам исследований было определено оптимальное расстояние между нижней частью жарового стакана и верхней частью горелки - от 0,005 до 0, 010 м.

В случае, когда горелка входит в полость жарового стакана доступ кислорода для горения снижает- 
ся. Визуально пламя приобретает желтый цвет, что говорит о неполноте сгорания. Расход газа в этом случае превышает оптимальное значение.

Повышенное значение расхода отмечено и при удалении горелки от жарового стакана на расстояние свыше 1,5 см. В этом случае пламя нестабильно и часто происходит его срыв из-за сквозняков в помещении.

На рисунке 4 представлены результаты испытаний АХП «Киев» АЛ-35 без турбулизатора потока продуктов сгорания в зоне подвода тепла генераторного узла АХA.

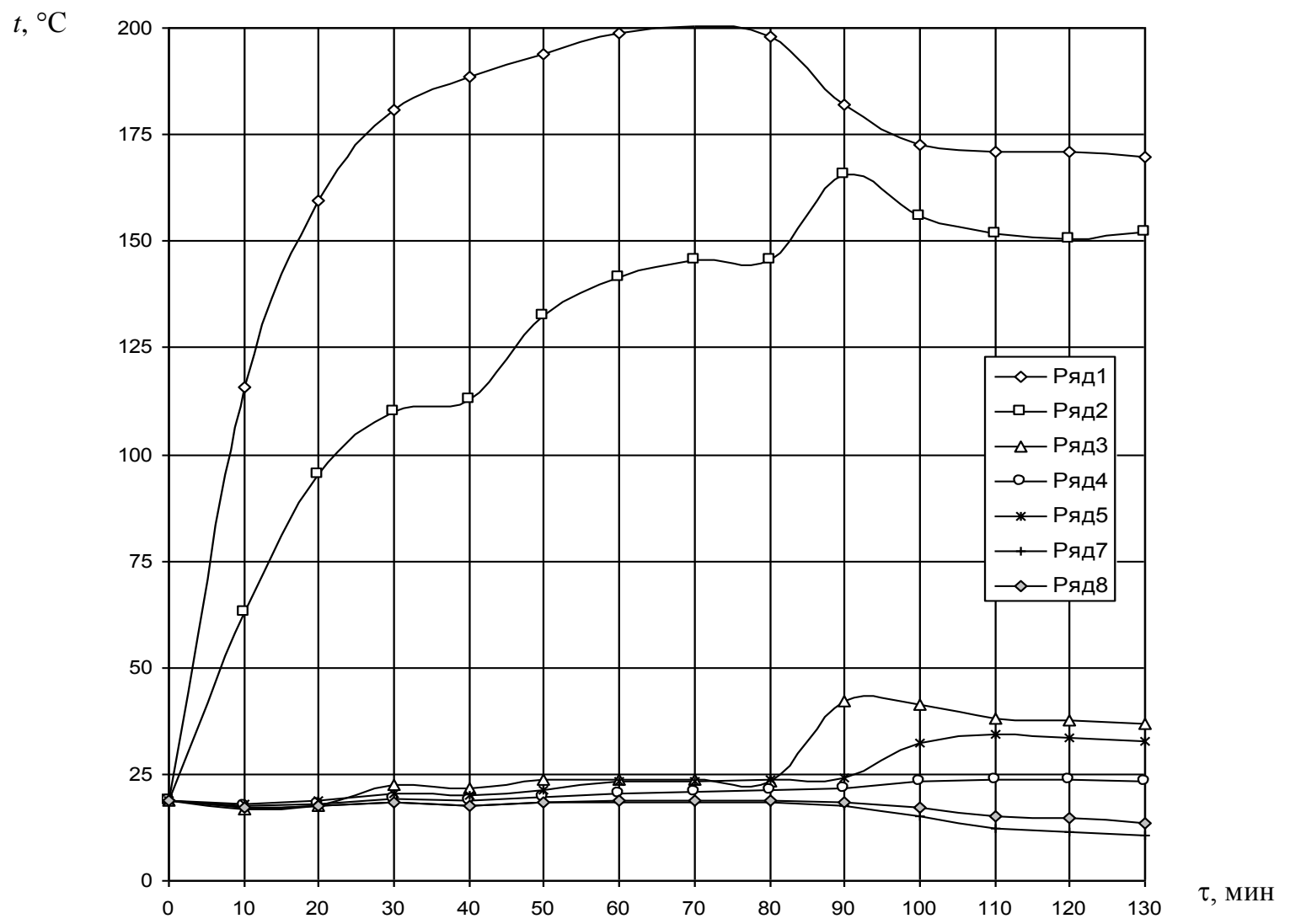

Рисунок 4 - Пусковой режим АХП «Киев» АЛ-35 без турбулизатора потока продуктов сгорания в зоне подвода тепла генераторного узла АХА: 1-5 - номера термопар в соответствии с рис. 3; термопара № 7 установлена на ребре панели испарителя; № 8 - в объеме холодильной камеры (геометрическом центре)

На рис. 5 представлены результаты испытаний АХП «Киев» АЛ-35 с медным турбулизатором потока горячих продуктов сгорания в зоне подвода тепла генераторного узла АХА.

На рис. 6 представлены результаты испытаний АХП «Киев» АЛ-35 с жестяным турбулизатором потока горячих продуктов сгорания в зоне подвода тепла генераторного узла АХА.

Испытания АХП «Киев» АЛ-35 показали целесообразность установки турбулизатора потока горячих продуктов сгорания в зоне подвода тепла генераторного узла АХА. Во-первых, значительно возрастала холодопроизводительность испарителя АХА. Так, при практически тех же затратах энергоносителя (244 г/сутки и 263 г/сутки) обеспечивалось снижение температуры на испарителе на $26^{\circ} \mathrm{C}$, вместо $8,5^{\circ} \mathrm{C}$ при работе без турбулизатора потока в условиях температуры воздуха в помещении $19^{\circ} \mathrm{C}$.

Результаты оригинального расчета АХП без турбулизатора потока дает значение холодопроизводительности 1,6 Вт, при наличии медного турбулизатора $-9,5$ Вт, жестяного - 9,4 Вт. В соответствии с массовыми расходами и теплоте сгорания пропана $47,54 \cdot 10^{6}$ Дж/кг тепловые нагрузки в испытаниях составляли: 134 Вт (без турбулизатора) и 145 Вт (с турбулизатором). Тепловой коэффициент АХА при сгорании органического топлива - 0,012 (без турбулизатора) и $0,065 \ldots 0,066$ (с турбулизатором).

Нестабильность работы генераторного узла без турбулизатора потока продуктов сгорания характеризуют и результаты, представленные на рисунке 7 имеют место значительные скачки температуры, что характеризует и значительные потери тепла с отходящими газами.

Проведено изучение этилового спирта и керосина в качестве теплоносителя горелочного устройства. Соответственно горелочными устройствами при проведении экспериментальных исследований были стандартная лабораторная спиртовка и бытовая керосиновая лампа (рисунок 8).

Результаты экспериментальных исследований пусковых характеристик транспортного абсорбционного холодильника с такими горелочными устройствами приведены на рис. 9 и рис. 10. 


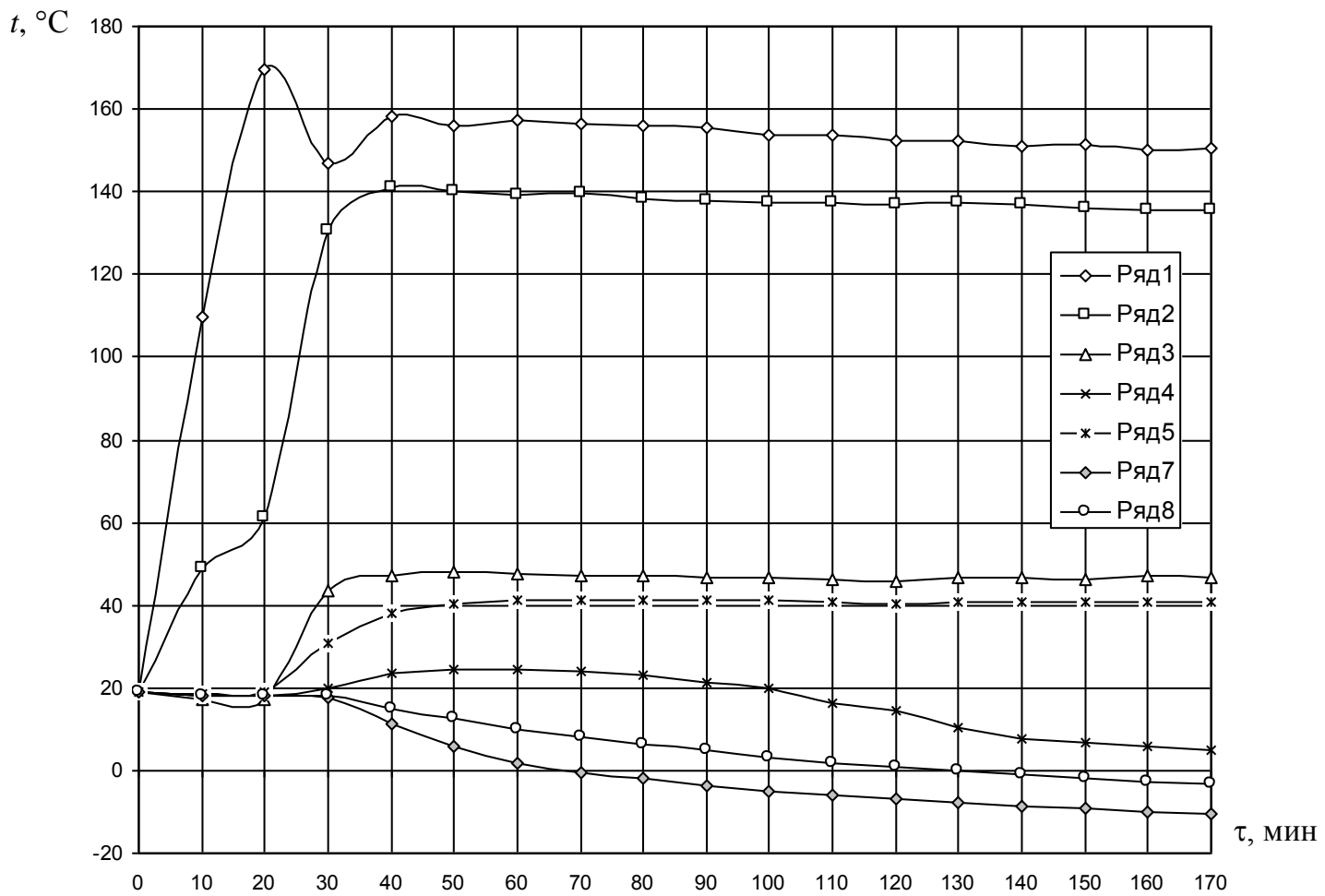

Рисунок 5 - Пусковой режим АХП «Киев» АЛ-35 с медным турбулизатором потока продуктов сгорания в зоне подвода тепла генераторного узла AXA: 1-5 - номера термопар в соответствии с рис. 3; термопара № 7 установлена на ребре панели испарителя; № 8 - в объеме холодильной камеры (геометрическом центре); температура воздуха в помещении $19^{\circ} \mathrm{C}$.

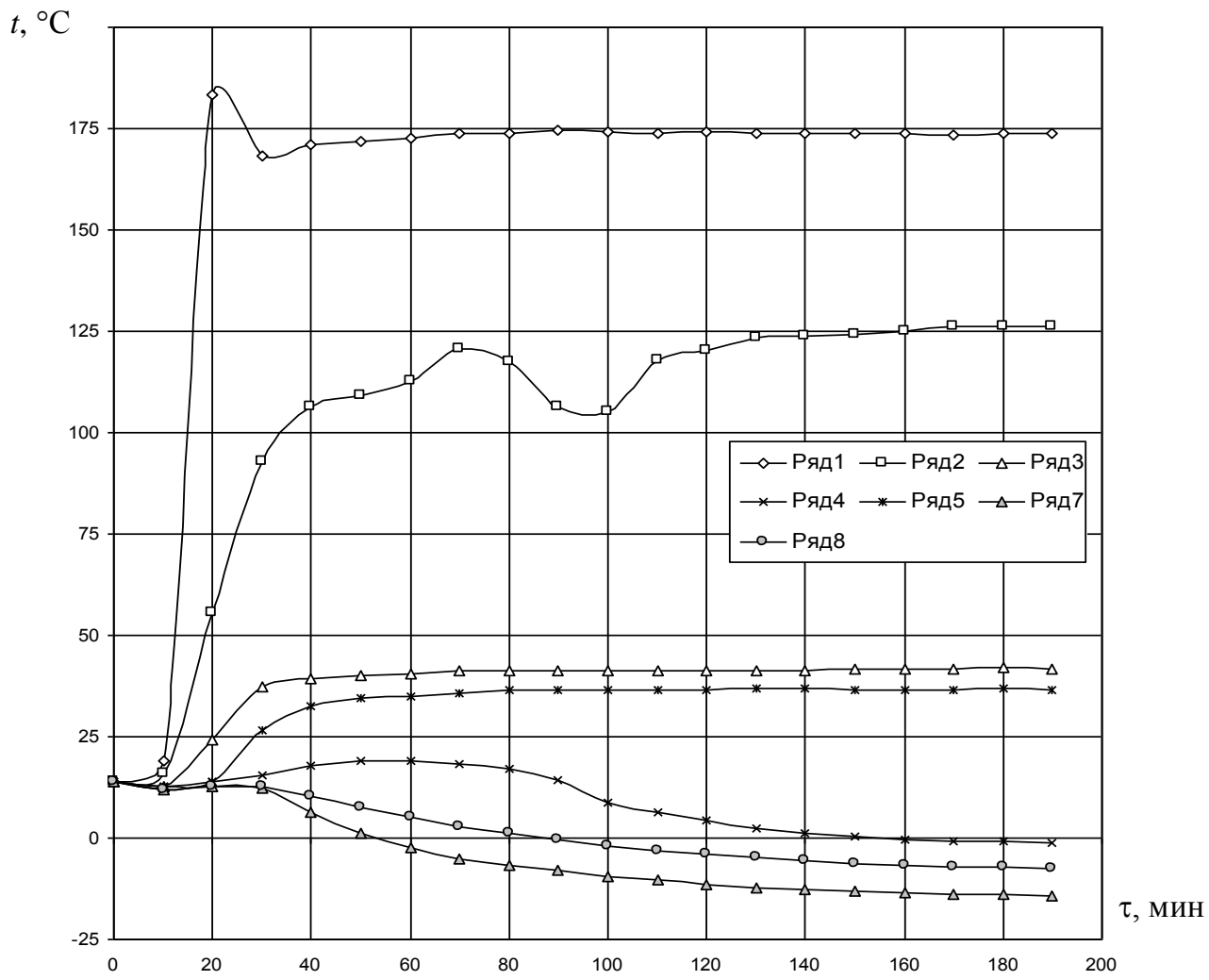

Рисунок 6 - Пусковой режим АХП «Киев» АЛ-35 с жестяным турбулизатором потока продуктов сгорания в зоне подвода тепла генераторного узла АХА: 1-5 - номера термопар в соответствии с рис. 3; термопара № 7 установлена на ребре панели испарителя; № 8 - в объеме холодильной камеры (геометрическом центре); температура воздуха в помещении $14^{\circ} \mathrm{C}$. 
$t,{ }^{\circ} \mathrm{C}$

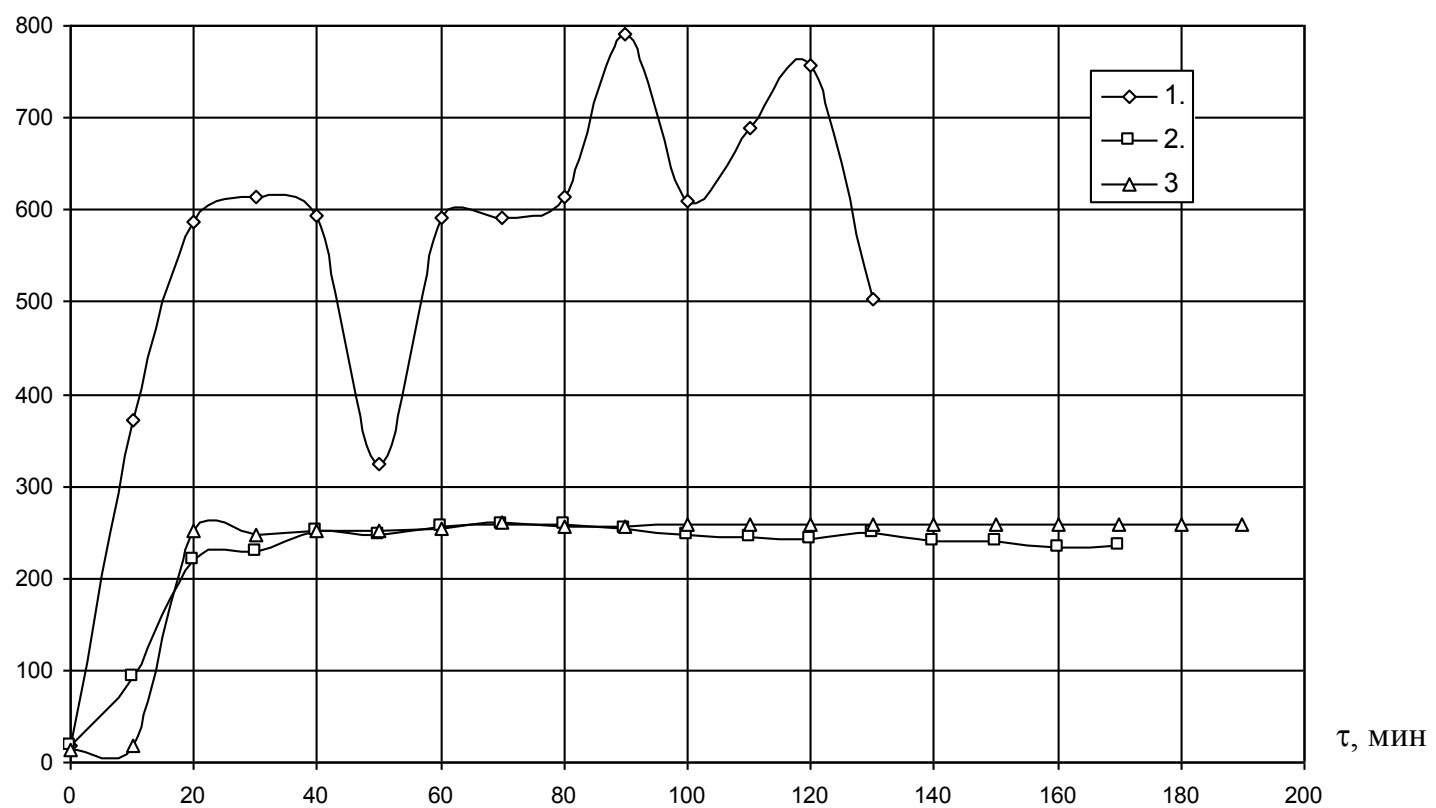

Pисунок 7 - Пусковой режим АХП «Киев» АЛ-35: 1 - без турбулизатора потока продуктов сгорания; 2 - с медным турбулизатором потока продуктов сгорания; 3 - с жестяным турбулизатором потока продуктов сгорания

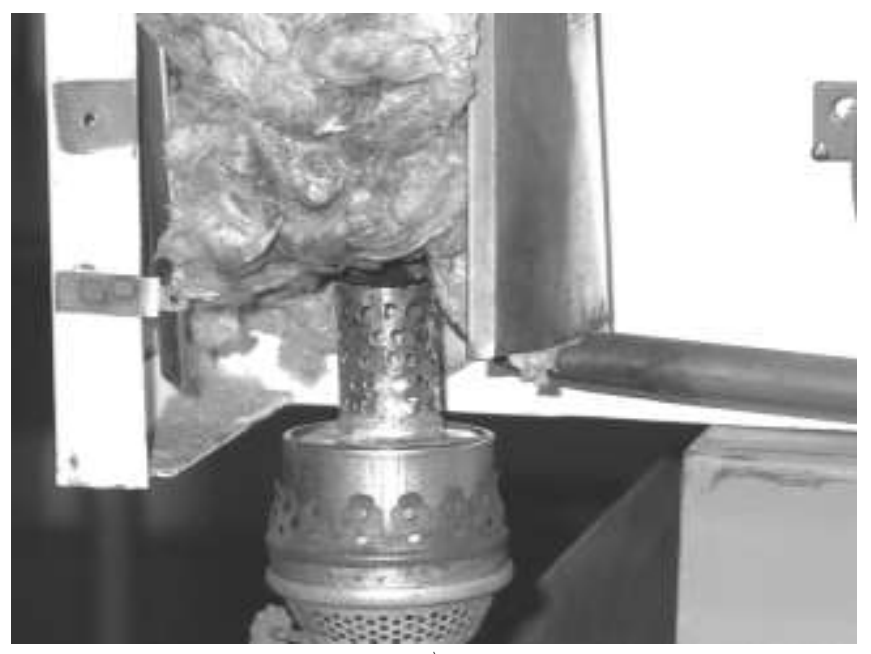

a)

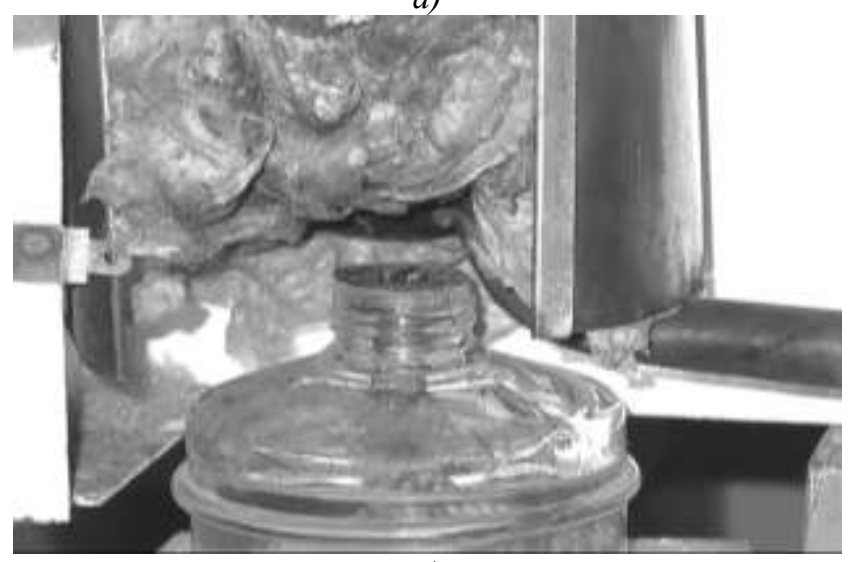

в)

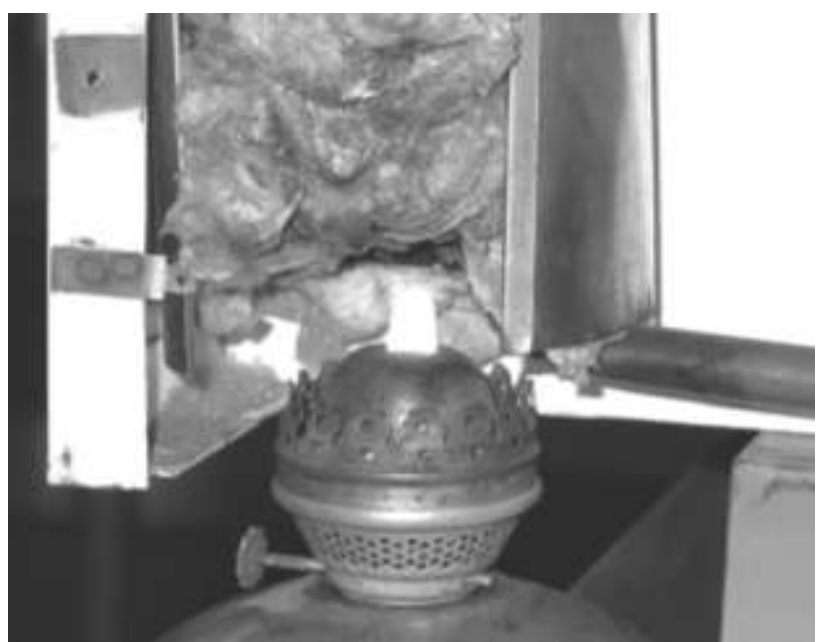

б)

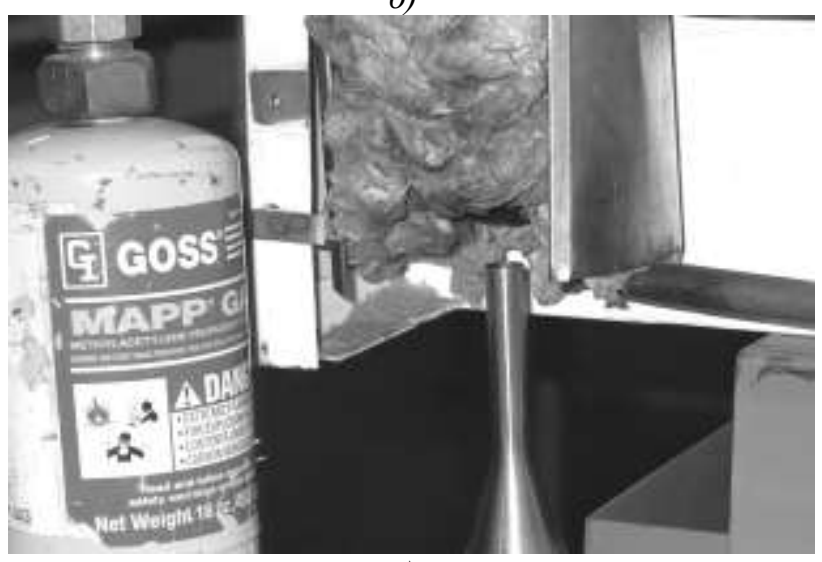

2)

Pисунок $\boldsymbol{8}$ - Горелочные устройства в экспериментальных исследованиях: а) керосиновая лампа со стабилизатором пламени; б) керосиновая лампа без стабилизатора пламени; в) спиртовая горелка (лабораторная спиртовка); г) неспециализированная газовая горелка 
$t,{ }^{\circ} \mathrm{C}$

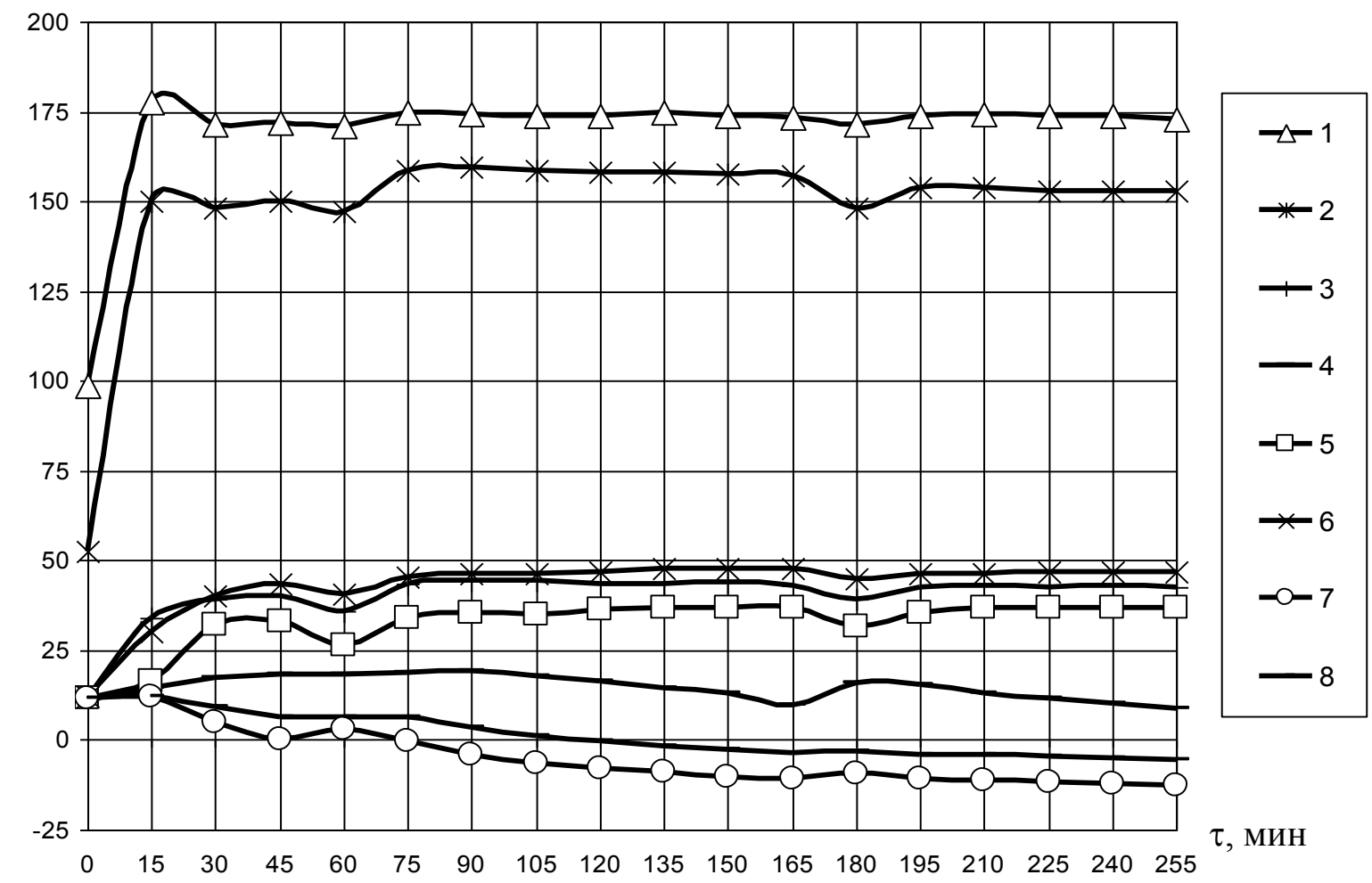

Рисунок 9 - Пусковой режим АХП «Киев» АЛ-35 при работе с этиловым спиртом в качестве теплоносителя: термопары 1-6 установлены в соответствии с позициями на рис. 3; термопара № 7 установлена на ребре панели испарителя; термопара № 8 - в объеме холодильной камеры (в геометрическом центре)

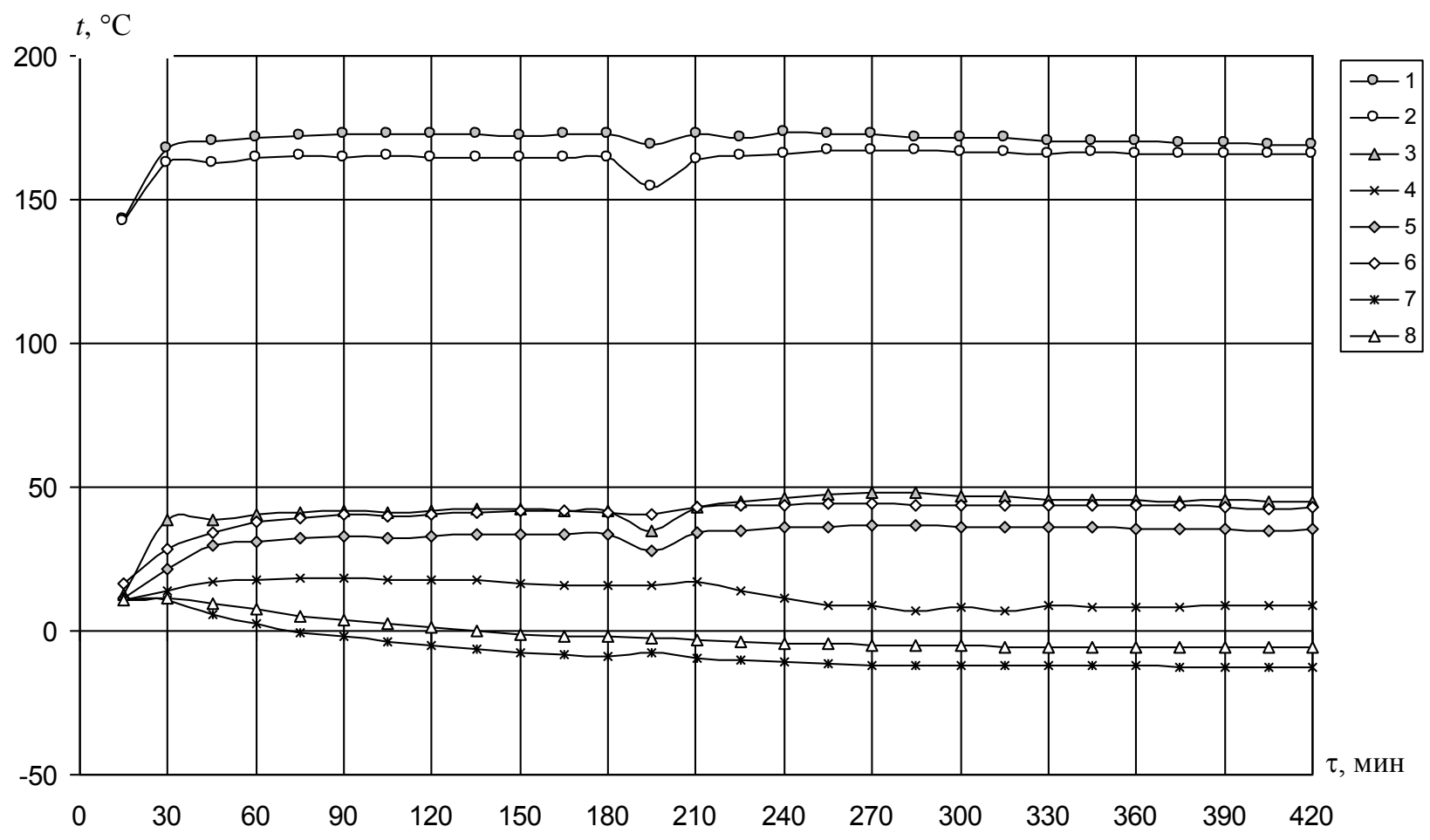

Рисунок 10 - Пусковой режим АХП «Киев» АЛ-35 при работе с керосином в качестве теплоносителя: термопары 1-6 установлены в соответствии с позициями на рис. 3.3; термопара № 7 установлена на ребре панели испарителя; термопара № 8 - в объеме холодильной камеры (в геометрическом центре) 
Массовый расход этилового спирта в экспериментальных исследованиях составил 0,307 кг/сутки, а керосина - 0,340 кг/сутки. Температура наружного воздуха составляла $16,5 \ldots 16,8^{\circ} \mathrm{C}$ при работе АХП на этиловом спирте и $17,0 \ldots 17,2^{\circ} \mathrm{C}$ - при работе АХП на керосине.

Турбулизаторы потока продуктов сгорания при работе на этиловом спирте и керосине не устанавливались, но вытяжной канал был закрыт. При открытом канале штатные режимы охлаждения не достигались.

Анализ результатов экспериментальных исследований показал, что:

a) при работе с этиловым спиртом и керосином достигаются необходимые режимы охлаждения в холодильной камере, причем из нерабочего состояния выход на режим с температурой не выше плюс $5{ }^{\circ} \mathrm{C}$ достигается за 85-90 мин;

б) при равных условиях работы отсутствие турбулизатора потока продуктов сгорания в вытяжном канале не позволяет обеспечить штатные режимы охлаждения.

\section{ВЫВОДЫ}

1. Проведенные экспериментальные исследования холодильника «Киев» АЛ-35 с горелочными устройствами показали его работоспособность при использовании различных доступных органических теплоносителей (этиловый спирт, керосин, сжиженный пропан) в транспортных условиях, в частности, на малой морской яхте. Такие результаты и характеризуют АХА как простое и надежное устройство

2. Разработано оригинальное горелочное устройство с применением каталитического источника горения, которое может решать задачи обеспечения требуемых режимов охлаждения при минимальных расходах теплоносителя - пропана.

\section{ЛИТЕРАТУРА}

1. Бабакин Б. С. Бытовые холодильники и морозильники / Б. С. Бабакин, В. А. Выгодин. - Рязань : Узоречье, 2005. - 860 с.

2. Титлова О. А. Анализ влияния тепловой мощности, подводимой в генераторе абсорбционного холодильного агрегата, на режимы работы и энергетическую эффективность абсорбционного холодильного прибора / О.А. Титлова, А.С. Титлов // Наукові праці OНАХТ. - 2011. - Вип. 39. - Т.1. - С.148-154.

3. Очеретяный Ю.А. Сравнительный анализ энергопотребления бытовых абсорбционных холодильников различного назначения / Ю.А. Очеретяный, А.С. Титлов, Н.Д. Захаров // Холодильна техніка і технологія. - 2007. - № 1. - С. 29-32.

4. Очеретяный Ю.А. Результаты испытаний транспортного абсорбционного холодильника с горелочным устройством // Холодильна техніка і технологія. - 2007. - № 2. - С. 34-37.

5. Прилади холодильні побутові. Експлуатаційні характеристики та методи випробувань : ДСТУ $3023-$ 95 (ГОСТ 30204-95, ISO 5155-83, ISO 7371-85, ISO 8187-91) - [Чинний від 1995-7-20] - К. : Держстандарт України, 1996. - 22 с. - (Національний стандарт України).

6. Прилади холодильні електричні побутові. Загальні технічні умови : ДСТУ 2295-93 (ГОСТ 16317-95 ISO 5155-83, ISO 7371-85, IEC 335-2-24-84).- [Чинний від 1995-7-20] - К. : Держстандарт України, 1996. - 35 с. - (Національний стандарт України).

Отримана в редакції 21.09.2016, прийнята до друку 01.11.2016

\title{
A. S. Titlov ${ }^{\bowtie}$, Yu. A. Ocheretyanyi, A. O. Holodkov, A. V. Ostapenko
}

Odessa National Academy of Food Technologies, 112 Kanatna str., Odesa, 65039, Ukraine

$\bowtie$ e-mail: titlow@mail.ru

\section{DEVELOPMENT AND RESEARCH OF TRANSPORT ABSORPTION REFRIGERATING UNITS GENERATORS}

\begin{abstract}
The experimental results of the absorption transport refrigerator "Kiev" AL-35 with burners which have shown its efficiency by using different available organic coolants (ethyl alcohol, kerosene, liquefied propane) in transport conditions, in particular at low sea yacht are given. The original burner device using catalytic combustion source that can meet the challenges of providing the required cooling mode at minimal cost of propane as a coolant has been developed.
\end{abstract}

Keywords: Absorption refrigerator; Burner device; Combustion intensifiers.

\section{REFERENCES}

1. Babakin, B.S., Vygodin, V.A. (2005). Household refrigerators and freezers. Ryazan: Uzoroche, 860 p. (in Russian).

2. Titlova, O.A., Titlov, A.S. (2011). Analysis of the influence of the thermal power supplied to the generator of the absorption refrigeration unit for operating modes and the energy efficiency of the absorption refrigerating unit. Proceedings Onaft, No. 39, vol.1, 148-154 (in Russian).

3. Ocheretyany, Yu.A., Titlov, A.S., Zakharov, N.D. (2007). Comparative analysis of the energy consumption of household refrigerators absorption of various purpose. Refrigeration Engineering and Technology, no.1, 29-32 (in Russian).
4. Ocheretyany, Yu.A. (2007). The test results of the transport absorption refrigerator with a burner device. Refrigeration Engineering and Technology, no. 2, 34-37. (in Russian).

5. Consumer Devices refrigeration. Performance and test methods: ISO 3023-95 (GOST 30204-95, ISO 5155-83, ISO 7371-85, ISO 8187-91) [Effective as of 07.20.1995]. K: State-standard Ukraine, 1996, 22 p. (National standard of Ukraine) (in Ukrainian).

6. Automatic electric refrigeration. General specifications: GOST 2295-93 (GOST 16317-95 ISO 5155-83, ISO 7371-85, IEC 335-2-24-84) [Effective as of 20.07.1995]. K: State Standard of Ukraine, 1996, 35 p. (National standard of Ukraine) (in Ukrainian). 